\title{
Women In Action: Challenges Facing Women Entrepreneurs In The Gauteng Province Of South Africa
}

Elizabeth Chinomona, Vaal University of Technology, South Africa

Eugine Tafadzwa Maziriri, Vaal University of Technology, South Africa

\begin{abstract}
In today's post-modern era, the role of women entrepreneurs in economic development is inevitable and women are willing to take action in business and contribute to the nation's growth. Women are stepping up to own and run businesses in numbers that would have been hard to imagine a mere few decades ago. However, women entrepreneurs face a wide variety of challenges both in starting and in growing their business ventures. The objective of this paper is to investigate the challenges women entrepreneurs face in the Gauteng province of South Africa. Exploring the challenges that women entrepreneurs face in South Africa, is of paramount interest to potential women entrepreneurs, researchers, the government of South Africa and other stakeholders. The paper used a qualitative research design using in-depth interviews and focus groups. The findings were that the challenges were identified as impediments to women entrepreneurs, which comprises lack of education and training, lack of access to finance, gender discrimination, negative attitudes and inadequate resources. Recommendations were made to women entrepreneurs, to the government of South Africa and other stakeholders. Lastly, limitations of this paper as well as future research directions were enunciated clearly.
\end{abstract}

Keywords: Gauteng Province; Human Capital Theory; Innovation; Women Entrepreneurs; Women Entrepreneurship; Challenges

\section{INTRODUCTION}

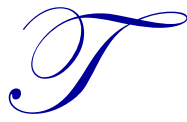

he International Labour Organisation (ILO) estimates that women entrepreneurs now account for a quarter to a third of all businesses in the formal economy worldwide (Nxopo 2014). South African economic policy places high value on entrepreneurship (Van der Merwe 2008). Governments look to entrepreneurship as a critical driver of growth and job creation. Entrepreneurship has been a male-dominated phenomenon, but time has changed the situation and brought women as today's most memorable and inspirational entrepreneurs, even in traditionally male dominated sectors such as construction (Vinesh 2014). According to Das (2001), women are increasingly turning to entrepreneurship as a way of coping with the 'glass ceiling' that seems to prevent them from reaching top managerial levels in organisations. Others have found that entrepreneurship provides them with greater satisfaction and flexibility. Akhalwaya and Havenga (2012) elucidate that women entrepreneurs in South Africa play a critical role in the economy of the country with regards to income and employment creation, as in any other African country. Women are now very active both mentally and physically in terms of business ventures. Women have realised that they can do what men do, or even better than them in terms of business ventures (Singh 2012). This paper will focus on women in micro enterprise businesses because women still tend to be concentrated in specific sectors, typically those with lower entrance requirements such as retail and service sectors.

Mandipaka (2014) explains that South African women entrepreneurs engage in survivalist activities such as sewing co-operatives, chicken farming, candle-making, gardening, arts and crafts. According to Akhalwaya and Havenga (2012), their contribution in business is mainly located in the areas of craft, hawking, personal services and 
retail sectors. Maas and Herrington (2006) point out that only 41 percent of the adult women in South Africa are part of the active working population. The TEA index (total early-stage entrepreneurial activity index) measured the percentage of women entrepreneurs between the ages of 18 and 64, involved in starting a business, at only 4.83 percent for South Africa. This is below the average of 7.72 percent as calculated for all countries (Maas \& Herrington, 2006:44). According to Singh (2012:46), in the process of entrepreneurship, women have to face various problems associated with entrepreneurship and these problems are doubled because of their dual role as a wage earner and a homemaker. To the best knowledge of the researchers, the challenges that women entrepreneurs face in the Gauteng province of South Africa have not been adequately studied and developed. Therefore, this research study focuses on the challenges faced by women entrepreneurs in the Gauteng province of South Africa for government to take action to promote women entrepreneurs.

The female entrepreneur's role is evident in growth leadership, management, innovation, research and development effectiveness, job creation, competitiveness, productivity and the formation of new industries (Nxopo 2014). Van der Merwe (2008) asserts that female entrepreneurship is increasing rapidly and women are starting their own business to take control of their personal and professional lives. Nxopo (2014) emphasised that the role these women entrepreneurs play to eradicate poverty and unemployment in South Africa cannot be underestimated and there is a need for research on the contribution and development of women entrepreneurs at all levels of the South African economy. Meyer (2009) points out that women entrepreneurs increasingly are considered important for economic development and they not only contribute to employment creation, but they also contribute to the diversity of entrepreneurship in the economic process.

The international definition of an entrepreneur is that he or she is an enterprise builder, perceives new business opportunities, creates businesses where none existed before, directs these businesses by using his or her own and borrowed capital, takes the associated risks and enjoys profit as rewards for the efforts (International Labour Organization, 2015). The South African definition is the same as the international definition. Nieman and Nieuwenhuizen (2009:9) define an entrepreneur as a person who sees an opportunity in the market, gathers resources, creates and grows a business venture to meet customer needs. An entrepreneur is an individual with a skill, mindset and the vision to start up a high-potential venture and the typically more seasoned, risk averse professional with the ability to scale the enterprise (Timmons \& Spinelli, 2009:4). An entrepreneur is, therefore, any individual who establishes a new firm, usually with considerable initiative and risk. These entrepreneurs play an indispensable role in ensuring that the economy continues to prosper and grow.

The rest of the paper is organised as follows. First, the problem statement and objectives are clearly stated. Human capital theory is drawn upon to support the paper's proposition. Thereafter, the literature for each of the research constructs is reviewed. What follows is an account of the research's methodology as well as a discussion on findings. Lastly, inferences are provided.

\section{Gauteng Province}

This paper aims to gather information that can be applied in the development of women entrepreneurship within the Gauteng province of South Africa. Figure 1.1 presents a geographical map of the Gauteng province of South Africa. 
Figure 1. Map of Gauteng

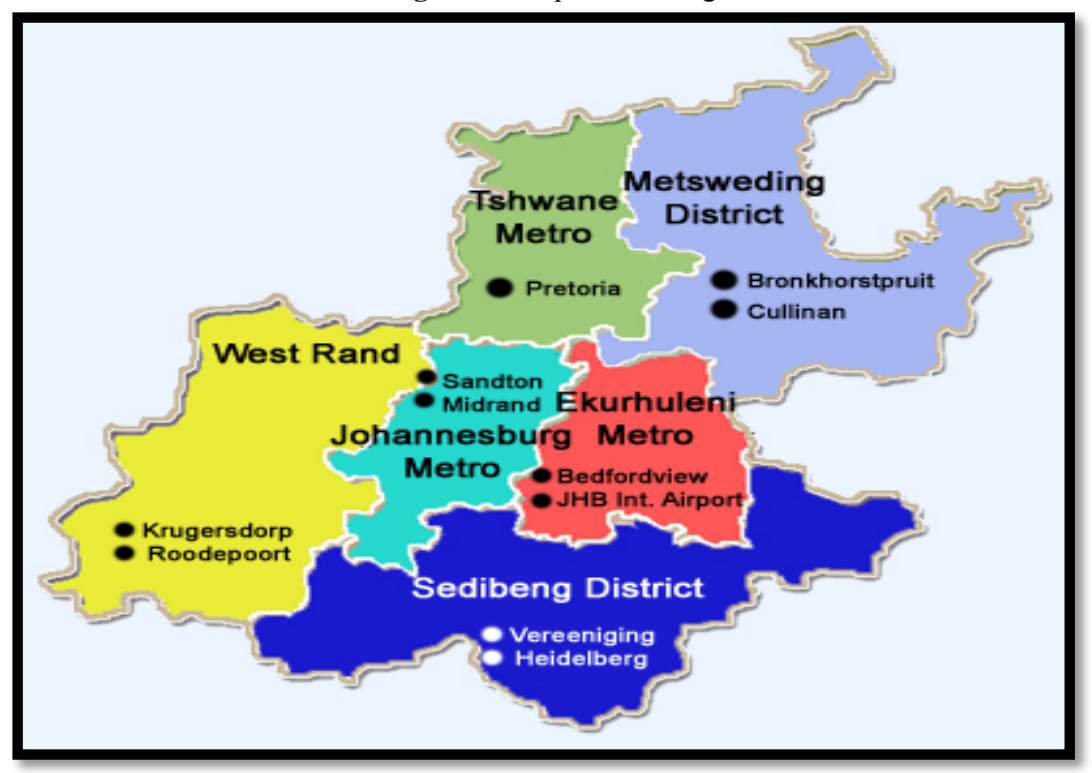

Source: http://gauteng.placetosleep.co.za/ accessed date: 1 April 2015

Gauteng, which means place of gold in Sesotho, is South Africa's smallest yet most dynamic and productive province (Kalombo, 2005). According to Mwakikagile (2008) and Kgagara (2011), Gauteng is not only the economic hub of South Africa, which contributes heavily in the financial, manufacturing, transport, technology and telecommunications sectors among others, it also hosts, more than any other country on the continent, a large number of overseas companies requiring a commercial base in, and gateway to, Africa (Kalombo, 2005). Gauteng province in South Africa is situated in the north-central part of the country (Senatla 2011). According to Knight, Harland, Telgen, Thai, Callender and McKen (2012) Gauteng is the smallest province in South Africa with an area of $21,025 \mathrm{~km}$. Although Gauteng constitutes only 1.7 percent of the total area of South Africa, 18.5 percent of the total South African population reside in the province (Knight, Harland, Telgen, Thai, Callender \& McKen 2012). Jogee and Callaghan (2014) are of the view that Gauteng is the most populous province, with the highest rate of urbanisation. Moreover, Senatla (2011) emphasises that although it is regarded as the smallest province in the country, it is the most famous province with approximately 10.5 million people ( $21 \%$ of the country's population) that occupy 3.175 million households. Despite being the smallest province, Gauteng is the powerhouse of the South African economy contributing a third of the country's GDP.

\section{PROBLEM STATEMENT}

Although women entrepreneurs significantly contribute to the success of an economy in various nations of the world, there are various challenges that hinder their entrepreneurial progress. According to Agbenyegah (2013), entrepreneurial activities in South Africa have shown a gradual decline over the years compared to other developing countries. Luiz and Mariotti (2011) state that South Africa has consistently ranked very poorly in the Global Entrepreneurship Monitor survey in terms of entrepreneurial activity. It is clear that South Africa is not producing a sufficiently entrepreneurial economy and this needs to be addressed so as to create employment, expand markets, increase production and revitalise communities (Luiz \& Mariotti 2011). Entrepreneurs are faced with many obstacles that limit their growth and survival (Nyamwanza, Mapetere, Mavhiki \& Dzingirai 2012). In addition to this, women have to cope with negative prevailing social and cultural attitudes, lack of education and training, as well as gender discrimination (Akhalwaya \& Havenga 2012). Even though the small business sector within the Gauteng province provides opportunities for existing entrepreneurs and for new venture creation, the question arises as to what barriers, problems, challenges and constraints women entrepreneurs encounter within the Gauteng province. The reason for the study is to explore the problems facing women entrepreneurs within the selected areas of the Gauteng province of South Africa and additionally this paper will advance the understanding of the barriers 
faced by women entrepreneurs within the Gauteng province of South Africa. The study will also look for possible solutions to minimise these challenges in the micro enterprises.

The objectives of this paper are to explore the problems that women entrepreneurs face in their day to day activities, to come up with solutions to the problems that women entrepreneurs are encountering, to explore the areas in which government and the private sector can intervene to assist women entrepreneurs with regards to the problems and to suggest practical recommendations of how to alleviate challenges faced by entrepreneurs in the Gauteng province of South Africa.

\section{SIGNIFICANCE OF THE STUDY}

There is need for a clear understanding of the challenges hampering the growth and development of these small ventures if meaningful solutions are to be implemented. Although some research has been conducted on entrepreneurship, it remains important to investigate challenges faced by women entrepreneurs operating in the Gauteng province of South Africa.

\section{LITERATURE REVIEW}

\section{The Human Capital Theory}

This paper adopts the human capital theory as its theoretical framework; this is because the human capital theory can be considered as critical to the formation of entrepreneurial ventures by women entrepreneurs within the Gauteng province of South Africa. According to Olabisi and Olagbem (2012), human capital has been considered as crucial to women entrepreneurial development. According to Kyalo and Kiganane (2014), the term human capital was used originally by Nobel economist Gary Becker, to refer to the stored value of knowledge or skills of members of the workforce. It has also been referred to in terms of the time, experience, knowledge and abilities of an individual household or a generation, which can be used in the production process (Heckman 2000:3). Human capital theory suggests that education or training raises the productivity of workers by imparting useful knowledge and skills, hence raising the workers' future income and life time earnings (Olabisi \& Olagbem 2012). This theory is based on the principle that the more workers invest in education and training the higher their earnings (Jones, Macpherson \& Thorpe 2010). Based on the authors' explanations it can be noted that the human capital theory proposes that the level of education, area of education, previous entrepreneurial experience, previous business experience and business skills, which influence the type of venture started. If the human capital theory is taken into consideration it can enhance the development of the entrepreneurship field, stimulate entrepreneurial attitudes and activities of the working population within the Gauteng province of South Africa. Human capital theory can help women entrepreneurs to be very active in business, thereby uplifting their living standards.

\section{Innovation}

In today's highly competitive global environment an entrepreneur's ability to introduce innovations is a key success factor for sustaining competitive advantage. In an increasingly interconnected world, national economies face stiff competition for markets, resources and skills. Consumers in turn are more demanding of originality and innovation (Heckman 2000). Similarly, Dess, Lumpkin and Fisher (2007:96) describes innovation as using new techniques to transform organisational processes or create commercially viable products and services. In simpler terms, innovation is the process of making improvements by introducing something new. Price, Stoica and Boncella (2013:3) define innovation as a process that begins with an invention, proceeds with the development of the invention, and results in the introduction of a new product, process or service to the marketplace. It has been described as the successful implementation of creative ideas, which can lead to solutions to problems that can have a potential impact on revenues of a firm, industry sector effectiveness, and the prosperity of nations (Price, Stoica and Boncella, 2013). Therefore, from the authors' definitions of innovation, it can be concluded that to be innovative indicates the ability to be creative, having successful use of an idea that adds value to the customer and commercial return for the creator and lastly, innovation is the process that renews something that exist or the birth of something new. 


\section{Women Entrepreneurs}

Although women entrepreneurs have become important players in the entrepreneurial landscape, it is imperative to clarify what are women entrepreneurs. Iyiola and Azuh (2014) define a woman entrepreneur as a female who plays a captivating part by repeatedly interacting and keenly adjusting herself with financial, socioeconomic, and support spheres in society. According to Manerkar (2015), women entrepreneurs may be defined as the women or a group of women who initiate, organise and operate a business enterprise. Women entrepreneurs start, own, operate, manage and take risks in their business (Thuaiba Azlah, Rozeyta, Hisyamuddin \& Noorizwan 2007). From the authors' definitions of a woman entrepreneur it can be concluded that a woman entrepreneur is the female front-runner of a business who takes the initiative of introducing a new venture, who accepts the associated risks and who is effectively responsible of its day-to-day activities. The most common aspects in the definitions is that women are involved in the operation and running of the business.

\section{Women Entrepreneurship}

Since entrepreneurship is both a complex and controversial concept, in order to comprehend the concept of women entrepreneurship it is imperative to start by noting or observing what entrepreneurship means. According to Chinomona, Maziriri and Moloi (2014) entrepreneurship is defined as the act of initiating, creating, building, expanding and sustaining a venture, building an entrepreneurial team, and gathering the necessary resources to exploit an opportunity in the marketplace for long-term wealth and capital gain. From the authors' definition, it can be seen that entrepreneurship is a capacity and willingness to develop, organise and manage a business venture in order to make a profit. Arakeri (2006:2) points out that women entrepreneurship comprises of an enterprise owned and controlled by a woman and having a minimum financial interest of 51 percent of the capital and giving at least 51 percent of the employment generated in the enterprise to women. From the definitions given it is possible to conclude and appreciate that women entrepreneurship is the process whereby an individual,develops a new venture or business unit. This can include an entrepreneurial individual acquiring an existing business or firm that is owned and controlled by a woman. Women in action in this paper merely mean women have been enlightened economically to be active in business but there are still some challenges that they face (Iyiola \& Azulu 2014).

\section{Challenges}

According to Stevenson (2010:287), a challenge is a situation that tests someone's abilities and points out that a challenge is a thing, action or situation that causes an obstruction; it blocks or hinders progress. Nani (2011:03) is of the view that a challenge is something needing great mental or physical effort in order to be done successfully. Challenges could be analogous to barriers. In line with this thought, Horn, Huygen, Woodward and Smith (2009:90) define barriers as obstacles that prevent movement or access. For the purpose of this paper, challenges will refer to those hurdles that hinder women entrepreneurs in their businesses, requiring them to use great mental effort. Additionally, challenges will be viewed as hurdles that make a woman entrepreneur's business not run effectively and efficiently.

\section{CHALLENGES FACED BY WOMEN ENTREPRENEURS}

The government of South African has been unable to solve the socio-economic issues of high unemployment and poverty reduction because of the constraints that hamper entrepreneurship (Agbenyegah 2013). Since the rise of democracy in 1994, the South African government has been placed under pressure to correct the socio-economic imbalances resulting from many decades of apartheid (Pooe, Mafini \& Makhubele 2015). In addition to this, Sibanda, Mishi and Tsegaye (2015) point out that since 1994, the South African economy has not managed to create sufficient employment opportunities, as evidenced by a relatively high average unemployment rate of 25.49 percent for the period 2000-2012.

It is imperative to understand the constraints facing women entrepreneurs in developing countries and specifically within the Gauteng province of South Africa. Parliament of the Republic of South Africa (1994) has indicated that poverty, inequality and unemployment have been identified as the three most serious constraints to economic development in South Africa and these three constraints are affecting females more than men. The 
colonial system and the regime rendered women entrepreneurs irrelevant. In South Africa, the birth of democracy brought changes in the business landscape. The Small Business Act of 1996, as reviewed by government, brought in some initiative to promote women entrepreneurs and deal with the challenges.

According to Phillips, Moos, Nieman (2014), since 1994 the government has devoted considerable resources to supporting small enterprises. They remark that although there have been dramatic changes in South Africa since 1994, particularly in the business environment; there are still not enough women entrepreneurs. Chiloane and Mayhew (2010) point out that in 2001 President Mbeki stated that the struggle for the rights of women continues after the long period of colonialism and apartheid, imposed oppression and exploitation, especially on black women. Research all over the world has shown that many interventions need to be made to fast-track the development of women entrepreneurs (Sarri \& Trihopoulou 2005).

The following are some of the challenges that women entrepreneurs face.

\section{Limited or No Access to Finance}

O'Neil and Viljoen, (2001) point out that the most crucial of these barriers is finance. Finance is regarded as "life blood" for any enterprise, be it big or small (Singh 2012:51). Wasilczuk and Zieba (2008: 160) believe that financial barriers are one of the most important obstacles women have to face when setting up and developing a business. Phillips, Moos \& Nieman (2014) point out that women entrepreneurs in South Africa have been particularly disadvantaged in the past as they do not own any property, which can be used as collateral on loans and need their husbands' permission to enter into financial arrangements. It is clear that women entrepreneurs suffer from inadequate financial resources and working capital and they are not able to acquire external financial assistance due to the absence of tangible security and credit in the market (Phillips et al. 2014).

\section{Gender Bias or Gender Discrimination of Women Entrepreneurs}

Sex discrimination, gender-bias or gender stereotyping is a challenge, which is faced, by most women entrepreneurs and being discriminated against in a male-dominated society hinders women entrepreneurs from being successful. Discrimination can be defined as distinguishing unfavourably or the detection of the difference between one thing and another (Mandipaka 2014). In South Africa, gender inequality is a big problem and South African women are still having problems being able to have the same rights and advantages as South African men (Mandipaka 2014). Mitchell (2004) posits that besides the risks entrepreneurs face, women face additional problems of being a woman in a male-dominated society. The core difficulty lies with the unwillingness of banks to grant credit, lack of support, the negative socio-cultural attitudes and sex discrimination or gender bias (Valla, 2001). Sinha (2005) propounds that although women entrepreneurs operate in the same environment as men entrepreneurs, there are gender biases embedded in society, which limit women from active economic participation and access to business and development services.

\section{Lack of Education and Training}

Running a business is very risky for any entrepreneur, even more so for women entrepreneurs who not only have to survive in a male-dominated environment but also often lack the education and training in this field (Phillips, Moos \& Nieman 2014). According to Ascher (2012:100), many women in developing countries remain illiterate and live in poor communities. Matiwane (2005) states that women entrepreneurs are ill-equipped educationally and financially. In a study conducted by Orford, Wood, Fischer, Herrington and Segal (2003) on the main obstacles faced by several South African entrepreneurs, the results of which indicated that the most recurrent weakness is lack of education and training among entrepreneurs. According to Jalbert (2000) for the woman entrepreneur, the process of operating a business can be very difficult in both the formal and informal sector because she often lacks the skills and education. Based on these authors' elucidations, it is clear that many women entrepreneurs lack training and education, which create problems for women in the setting up and running of business enterprises. 


\section{GENERAL SOLUTIONS TO THE CHALLENGES FACED BY WOMEN ENTREPRENEURS}

\section{Finance}

In order to alleviate the financial challenge facing women entrepreneurs, it is imperative for the government of South Africa to acknowledge the importance of women entrepreneurs to the South African economy as well as giving them the financial support they need in order to prosper. Gangata and Matavire (2013) point out that the government should play its role in enabling entrepreneurs to obtain funds at affordable interest rates, for example by reducing the rates charged by financial institutions or creating special funds, which can be accessed by entrepreneurs without too much red tape. The government can provide group loans for the poor and marginalised rural people to develop income-generating activities (Gorora \& Mago 2013).

Nyanga (2013) explains that it is imperative for the local government and financial institutions to come forward to help the entrepreneurs to have easy access to loans. According to Gangata and Matavire (2013), the government should also provide training to entrepreneurs in areas like financial and strategic management, to ensure proper management of these important entities and the government should also look at the possibility of opening a bank to cater for the needs of entrepreneurs. Ochieng and Sije (2013) state that people should be encouraged to learn how to write business proposals in order to access credit. When designing a proposal, women are expected to come up with realistic, attainable and measurable goals (Ochieng \& Sije, 2013). Valla (2001) postulated that financial institutions need to be seen as more supportive of the initiatives of female entrepreneurs and they need to ease the administrative procedures for the establishments and operation of women entrepreneurs as well as revisit their assessment criteria of women's application for loans. They may have to include other "softer" assessment criteria than the traditional ones in connection with lending to women (Valla, 2001:100).

There are many ways in which women entrepreneurs can gain financial support. According to Greve (2009), financial support might take the form of grants, subsidised loans or loan guarantees to credit providers, tax credits and exemption from business registration fees. Therefore, the government can provide woman entrepreneurs with special subsidies, funds, enterprise centers, entrepreneurship awards, counselling and advisory support (Nxopo 2014). Iwu and Nxopo (2015:10) point out that although government has tried to put in place policies and institutions with an aim of improving access to finance by female entrepreneurs; their success has been minimal. Therefore, it is imperative that management capability and financial management acumen be regarded as key to access funding by the entrepreneurs themselves and the parties involved in supporting and promoting them (Iwu \& Nxopo 2015). Cupido (2002) points out that most applicants do not know what is expected of them when making application to financial institutions for assistance and the Department of Trade and Industry has a business referral and information network website to assist entrepreneurs in this area. The institutions that have been outsourced to act on behalf of the Department of Trade and Industry are:

- $\quad$ Khethani Business Finance (Khula RFI)

- $\quad$ Landelike Onwikkelings Maatskappy

- $\quad$ Nations Trust (Khula RFI)

- $\quad$ New Business Finance.

Moreover, since most women do not have easy access to credit for their entrepreneurial activity, the Government of South Africa together with financial institutions can introduce micro-credit schemes. Idris and Agbim (2015:124) assert that micro-credit is a small loan usually given to the working poor, most often for the purpose of income-generating employment. Yogendrarajah (2011) conducted a study with the prime objective of identifying the role of micro-credit programmes in empowering women in Jaffna region under post-war development. The results showed that there is a positive correlation between micro-credit and women empowerment. Similarly, Nkpoyen and Bassey (2012) conducted a study to assess micro-lending as an empowerment strategy for poverty alleviation among women in Yala LGA of Cross River State, Nigeria. The results revealed that increased savings, promotion of local cooperative societies and creation of self-employment opportunities are related significantly to poverty reduction. Therefore, micro-credit can act as a powerful economic development enabler and an important tool in alleviating the challenge of not having access to finance among women entrepreneurs within the Gauteng province of South Africa. 


\section{Fostering Entrepreneurship Education and Training Among Women Entrepreneurs}

Alberti, Sciascia and Poli (2004) stress that entrepreneurship education aims at building the so-called entrepreneurial competencies, which are considered as combinations of different entrepreneurial skills, knowledge and attitudes. Arogundade (2011:27) described entrepreneurship education as structured to enable individuals to be self-employed and self-reliant; enable people to be creative and innovative in identifying business opportunities; serve as a catalyst for development and economic growth; reduce the level of poverty; create employment opportunities; reduce rural-urban migration; empower tertiary institution graduates with adequate training in risk management and to inculcate the spirit of persistence in people, which will enable them to persist in any business venture. According to the ILO latest update cited by Stevenson \& Onge (2005), if young women are encouraged to obtain higher levels of education, they will be better equipped to receive guidance, retraining and re-direction in the pursuit of more productive and growth-oriented businesses. Daymard (2015) suggests that in order to foster female entrepreneurship it is imperative to ensure that all children complete mandatory education and young women are encouraged to pursue higher education.

Van der Merwe (2002:48) elucidates that it is imperative to focus on the training of entrepreneurs, particularly the development of previously disadvantaged individuals, specifically women entrepreneurs. According to Bajpai (2014), women entrepreneurs require pre-entrepreneurial training to plan an organised business venture successfully. Botha (2006:146) argued that there is a need for training programs designed specifically for women entrepreneurs. The literature confirms that skills training and business education have a positive effect on enterprise performance (Akanji, 2006; Cheston \& Kuhn, 2002; Kuzilwa, 2005).

Additionally, Botha (2006:146) advised that a women entrepreneurship program should include the following areas of importance: financial assistance, management assistance and training as well as networking, mentoring and counseling. Based on the authors' descriptions, if entrepreneurship education and training is nurtured among women entrepreneurs, the entrepreneurship activity rate will rise without any difficulties in the Gauteng province of South Africa.

\section{Gender Bias or Gender Discrimination.}

Since the common perception is that women confront stereotypical attitudes on a daily basis in their contacts with banks, clients and suppliers in the management phase of their business it is imperative to find strategic ways of alleviating gender bias. Ascher (2012:110) suggests that in order to alleviate gender bias, policy-makers should perceive female entrepreneurs as a special group that deserves special attention, as well as promoting equal opportunities. In order to alleviate the challenge of gender discrimination, women entrepreneurs need to be empowered. Empowerment is a process by which individuals and groups gain power, access to resources and control over their lives (Budeli, 2012). Véras (2015:52) defines women's empowerment as their ability to make strategic life choices, where this ability had been denied previously. Women are still economically and socially disadvantaged in many countries, so the promotion of gender equality and empowerment of women is one of the United Nation's Millennium Development Goals (Véras, 2015).

\section{METHODOLOGY}

This paper employed an interpretative, qualitative methodology to examine the challenges faced by women entrepreneurs in the Gauteng province. Furthermore, field researches investigated the views and opinions of entrepreneurs directly and indirectly by means of in-depth interviews, focus groups and observations. Therefore, this paper adopted a data triangulation approach. The researcher interviewed thirty (30) women entrepreneurs in the Gauteng province, whose businesses are registered according to the laws and regulations of South Africa. The list of registered companies was obtained from the Small Enterprise Development Agency (SEDA) database. The researchers interviewed 10 women from Vanderbijlpark, 10 from Vereeniging, and 10 from Roodepoort in the urban areas of the Gauteng province. A convenience sampling method was used to select the respondents. The respondents were chosen for the purpose of providing inside information about challenges they are facing as women entrepreneurs. The researchers managed to conduct the interviews while at the same time recording the interviews and taking short notes for future coding. The general observation was that each interview would trigger the necessity 
for another interview as the themes began to unfold. The convergent in-depth interviewing used in this study allowed the researcher to develop, clarify, verify and refine the core issues of the interview protocol. Unlike in quantitative research, qualitative research views literature review as an ongoing process and serves as a source of data (Bryman 2004).

Document exploitation was also done in this paper to authenticate the findings. As put forward by Cooper and Schindler (2011), the literature from documented material should be viewed equally, the same as field notes. The same point was buttressed by Wilson (2010) who referred to documented literature as "everything is data" and Strauss and Corbin (1990) who asserted that a "cache of archival material" is equivalent to a collection of interviews and field notes. For confidentiality reasons, the identity of respondents was not disclosed. Conclusion, limitations of the study and suggestion of future research direction conclude the current study.

The study conducted a focus group of 10 female entrepreneurs from the 3 in Roodepoort, 3 in Vereening and 4 in Vanderbijilpark for different cities in the Gauteng province. For convenience reasons and to cut some costs, the focus group was conducted in Vanderbijilpark because Vereening is close to Vanderbijilpark and the researchers used a venue at the university at no cost. A focus group is a form of quantitative research in which a group of people are asked questions about their opinions, perceptions, beliefs and attitudes towards a product, service, concept or idea (Bradley 2007; Wilson 2010). Bryman (2004) and Cooper and Schindler (2011) defined a focus group as an interview conducted by a trained interviewer among a small group of respondents. Questions are asked in an interactive group setting, where participants are free to give views from any aspect and talk with each other. A focus group allows interviewers to study people in a more natural conversation pattern than typically occurring in a one to one interview. A tape recorder was used to record the conversation. The researcher then wrote everything down listening to the tape recorder, including pauses. However, there is the disadvantage of observer dependency raising questions of validity unless the interviewing of the focus group is repeated several times (Zikmund, Babin, Carr \& Griffin, 2010). This helped a lot in singling out the challenges that are faced by women entrepreneurs in the Gauteng province and the solutions they think might help them in the long run. The researcher singled out that there is a great need for women to be assisted to enable them to excel and become more active in research and the most important challenge that was singled out was lack of financial resources.

\section{FINDINGS AND DISCUSSIONS}

According to Mouton, Louw and Strydom (2013:32), the South African education system remains in a state of transformation as the government is in a process of grappling with legacies of the past, whilst balancing risks and opportunities for the future. South African students score poorly in literacy and numeracy tests when compared with students from other African countries and when considering what should be expected almost 20 years after the achievement of democracy (Human Sciences Research Council, 2012). In South Africa, two out of ten learners drop out of school after Grade 3, four out of ten after Grade 9, six out of ten after Grade 10 and 7.3 after Grade 11; this means that less than a quarter of learners who begin Grade 1 complete Grade 12 (Pather, 2011). According to the Centre for Education Policy Development (CEPD) (2009), South Africa has a high-cost, low-performance education system that does not compare favourably with education systems in other African countries, or in similar developing economies. Mbenzi (2011:25) points out that holding a tertiary qualification significantly increases the probability that an individual will be an owner or a manager of a business. Therefore, a lot needs to be done to have efficient and effective education, which results in global competitiveness. This issue of education problems affects women the most and government and the community should do something. If more women are educated this can improve the image of South Africa at all angles, be it economically, socially, politically or technologically. However, it is worth noting that the levels of tertiary education for South African women are rising steadily. Increasing numbers are obtaining qualifications in traditionally male fields such as engineering (Mbenzi, 2011; Akhalwaya \& Havenga, 2012). The narrowing of the gap in tertiary studies could in time help to generate more women entrepreneurs in these fields.

The findings of this study also indicated that lack of education and training is a challenge hampering the success of women entrepreneurs living in the Gauteng province of South Africa. The results of this research paper are in consistence with literature. Herrington and Wood (2003) explained that education and training system is regarded as the number one limiting factor for entrepreneurship in South Africa. Fatoki and Garwe (2010) also 
confirm that entrepreneurship education is still one of the prime factors limiting the growth of the economy in South Africa.

The findings of this study also revealed that women entrepreneurs living in the Gauteng province of South Africa experience some hardships in obtaining start-up capital. The interviewed women entrepreneurs emphasised that access to finance is one of their biggest challenges and as a result they end up using their own meagre funds to start up business ventures. Other women entrepreneurs were of the view that commercial banks were reluctant to offer loans to them because banks are not confident in the abilities of women to manage businesses. This is in line with Pretorious and Shaw (2004) and Atieno (2009) findings that access to start-up capital is a major stumbling block to venturing in a new business. Additionally, Akhalwaya and Havenga (2012) confirm that the inability to obtain external finance from sources such as commercial loans and equity, including sources of external bootstrapping from customers and suppliers poses a barrier for women entrepreneurs.

Data from the study revealed that most women entrepreneurs experience gender discrimination and this limits women from active economic participation and access to business and development services. This is in line with Adeel-Anjum, Khan, Naz, Raza and Fatima (2012) who emphasised that gender-based discrimination is one of the major factors restraining women from business.

The findings also prove that negative perceptions and attitudes from the members of the community as well as family members hinder them from successfully operating their businesses. Moreover, these results also agree a quantitative study conducted by Akhalwaya and Havenga (2012) to investigate the barriers that hinder the success of women entrepreneurs in Gauteng province, South Africa. The results indicated that negative attitudes discourage women from taking risks in business and the social environment deters them from pursing career paths in science, engineering and technology.

Lastly, women entrepreneurs, especially those who are running businesses in the line of sewing, knitting, printing and fast foods, emphasised that inadequate resources or equipment obstruct them from succeeding in the entrepreneurial ventures. These results are in line with works of Jebadurai (2007) who revealed that entrepreneurs cannot produce quality products due to lack of standardised equipment and poor quality of raw materials.

\section{CONTRIBUTIONS, RECOMMENDATIONS AND IMPLICATIONS OF THE STUDY}

The paper has both theoretical and practical contributions. This is the first paper to the best knowledge of the researcher that applied the Human capital theory in entrepreneurship literature. Which means the theory added new knowledge to the existing literature on entrepreneurship. The paper has a practical contribution to women to be active in entrepreneurship both physically and mentally through education and hard working.

There is need to instil a spirit of entrepreneurship in the Gauteng province, especially among women. A lot needs to be done to have efficient and effective education, which results in global competitiveness. Universities alone cannot do the change in terms of grooming women entrepreneurs; it requires participatory approach from all angles. High quality education and high standards and relevance of education can lead to institutions of higher learning having quality graduates who can be employable and have a sustainable advantage everywhere. The current study is an attempt to undertake a research in an often neglected area but yet an important sector of the South African businesses. The findings of this empirical study are expected to provide fruitful implications across all stakeholders in South Africa's tertiary institutions to put more emphasis on entrepreneurship as it brings money to the government, provides employment and alleviation of poverty, for women in particular. All stakeholders need to be involved in decision-making, including the parents, for efficacy to be realised and change how people view women entrepreneurs. But there is need to provide adequate resources for this dream of uplifting women entrepreneurship to be realised. Kayamba (2007) asserts that government policy-makers in South Africa have put in place programmes to improve the situation of women in business. Therefore, it is imperative for women entrepreneurs living in the Gauteng province of South Africa to be aware of entrepreneurial support schemes, which are organised by the government of South Africa; for example the Khula Enterprise Finance, Ntsika Enterprise Promotion Agency and the Small Enterprise Development Agency (SEDA). It is best for the South African government to focus on providing equipment and developing infrastructure to support women entrepreneurs. The 
South African government should strive to improve intellectual capacity among women entrepreneurs on entrepreneurship education by expanding and strengthening tertiary education. Verheul, Van Stel and Thurik (2004) are of the view that the government can provide female entrepreneurs with special loans, subsidies, funds, enterprise centres, entrepreneurship awards, counselling, training, advisory support, information products and web portals. Therefore, the South African government should come up with a considerable dedicated fund especially for women entrepreneurs in order to support their entrepreneurial activities.

The key recommendations to the women entrepreneurs living in the Gauteng province of South Africa include the following: Women entrepreneurs should raise confidence, empower themselves through entrepreneurial education, which is one of the initiatives that can be designed to enhance skills and knowledge in entrepreneurship. It is recommended that women entrepreneurs should acquire skills that will help to break the stereotypes and value systems that hinder them from participating in everyday activities. Women entrepreneurs should form partnerships with individuals from different areas of knowledge and expertise in order to learn from one another.

\section{LIMITATIONS AND FUTURE RESEARCH}

In spite of the contributions of this paper, it has its limitations, which provide avenues for future researches. First and most significantly, the present research is conducted from the entrepreneurs in Gauteng province. Perhaps if data collection is expanded to include other provinces, findings might be more insightful. Future studies should, therefore, consider this recommended research direction. The research was also conducted in urban areas only, future research might focus on both urban and rural areas. There is also the problem of common method bias because qualitative research was used in this study. It would have been more robust if the study included both qualitative and quantitative methods. All in all, these suggested future avenues of study stand to immensely contribute new knowledge to the existing body of entrepreneurship literature, a context that happens to be less studies by researchers in Africa.

\section{CONCLUSION}

This study has examined the five key words, namely women entrepreneurship, innovation, women entrepreneurs, challenges, Gauteng province. Many authors have tried to define these most important concepts differently. For positive change to be realised around these five aspects there is need for all people to come together and have an input to ensure that all views are included in decision making for women empowerment. It is important to note that students, especially women, should be afforded opportunities and resources to make decisions and learn about entrepreneurship. The greatest challenge facing entrepreneurs in the Gauteng province is lack of resources. There is need for government to allocate more financial resources to women entrepreneurs especially those still at the introductory stage. Government should allocate more funds to micro businesses operated by women because financial problems is one of the greatest issue that is affecting women to be in action in terms of entrepreneurship.

\section{AUTHOR INFORMATION}

Elizabeth Chinomona is a married woman with three children. Her first degree is from the University of Zimbabwe and her Masters with National Cheng Kung University in Taiwan. Currently she is working as a lecturer at Vaal University of Technology in the Logistics Department, South Africa and is also studying towards her PHD at the same university. Research is her passion as she has always learned a lot from it and also disseminate knowledge to others. Research areas include entrepreneurship, marketing, supply chain and human resources management. Email: chakubvae@hotmail.com.

Eugine Tafadzwa Maziriri is single and is Zimbabwean by birth. On an academic level, he holds a Bachelor of Technology Degree in Business Administration from the Vaal University of Technology. Currently he is studying towards his Master's Degree in Business Administration at the same university. He is an emerging researcher interested in researching in areas of entrepreneurship, retail management, marketing, and human resources management. Email: euginemaziriri@yahoo.com. 


\section{REFERENCES}

Adeel Anjum, M., Khan, N., Naz, H., Raza, S.A \&Fatima, S. (2012). Problems and prospects of women entrepreneurs: a case study of Quetta-Pakistan. International Journal of Business and Social Science. 3(23) 177-183.

Agbenyegah, A.T. (2013). Challenges facing rural entrepreneurship in selected areas in South Africa. PhD thesis Business Administration. North West University.

Akanji, O.O. (2006). Microfinance as a Strategy for Poverty Reduction. Central Bank of Nigeria Economic and Financial Review, 9(4):1-20

Akhalwaya, A., \& Havenga, W. (2012). The Barriers that hinder the success of Women Entrepreneurs in Gauteng; South Africa. International Journal of Sustainable Development; 3(5) 11-22

Alberti, F., Sciascia, S., \& Poli, A. (2004). Entrepreneurship education: notes on an ongoing debate. Proceedings of the 14th Annual International Entrepreneurship Conference. University of Nopoli, Federico II, Italy, 4-7 July.

Arakeri, S.V. (2006). Women Entrepreneurship in India. National Monthly Refereed Journal of Research in Arts \& Education. 1(3) 1-7.

Arogundade, B.B. (2011). Entrepreneurship education: an imperative for sustainable development in Nigeria. Journal of emerging trends in educational research and policy studies, 2(1):26-29.

Ascher, J. (2012). Female Entrepreneurship - An Appropriate Response to Gender Discrimination. Journal of Entrepreneurship, Management and Innovation. 8(4) 97-114.

Atieno, R. (2009). Linkages, access to finance and the performance of small-scale. Research paper. Institute for Development Studies, Nairobi. University of Nairobi.

Bajpai, G.C. (2014). African Women Entrepreneur: Problems, Challenges and Future Opportunities. International Journal of Managerial Studies and Research. 2(5) 17-22.

Botha, M. (2006). Measuring the effectiveness of the women entrepreneurship programme, as a training intervention, on potential, start-up and established women entrepreneurs in South Africa. Pretoria: University of Pretoria. (Unpublished PhD. thesis).

Bryman, A. (2004). Social Research Methods. $2^{\text {nd }}$ ed. Britain: Oxford University Press.

Budeli, M.C. (2012). Barriers and coping capacities experienced by people living with disability in the Nzhelele area of Limpopo province. Magister Artium thesis. (Unpublished Thesis). University of Johannesburg. ICentre for Education Policy Development (CEPD) (2009). Challenges facing education in South Africa. Retrievedfromhttp://www.cepd.org.za/files/pictures/The\%20Challenges\%20Facing\%20Education $\% 20$ Inter view\%20Nov\%2009.pdf.

Cheston, S. \& Kuhn, L. (2002). Empowering Women through Microfinance. A Case Study of Sinapi Aba Trust, Ghana. USA: Opportunity International.

Chiloane, G.E., \& Mayhew, W. (2010). Difficulties Encountered By Black Women Entrepreneurs in Accessing Training from the Small Enterprise Development Agency in South Africa. Gender \& Behaviour, 8(1) 25902602.

Chinomona, E., Maziriri, E., \& Moloi, K.C. (2014). Corporate entrepreneurship with innovation in mind in one university of technology in South Africa. Mediterranean Journal of Social Sciences. 5(23) 20-29.

Cooper, D.R. \& Schindler P.S. (2011). Business research methods. $11^{\text {th }}$ ed. Singapore: McGraw-Hill.

Cupido, C. (2002). Barriers to entrepreneurship in the Western Cape. Master of Business Administration thesis. Cape Town. Cape Technikon.

Das, M. (2001). Women Entrepreneurs from India: Problems, Motivations and Success Factors. Journal of Small Business and Entrepreneurship. 15(4) 67-81.

Daymard, A. (2015). Determinants of Female Entrepreneurship in India. Working paper. Organization for Economic Co-operation and Development.

Deborah, A.E., Wilhelmina, S., Oyelana, A.A \& Ibrahim, S.I. (2015). Challenges Faced by Women Entrepreneurs and Strategies Adopted by Women Entrepreneurs to Ensure Small Business Success in Nkonkobe Municipality, South Africa. Journal of Economics, 6(1): 37-49.

Dess, G.G., Lumpkin, G.T. \& Eisner, A.B. (2007). Strategic management. Boston, MA: McGraw-Hill Irwin Early Childhood council- ECC (2015). What is an Entrepreneur? The Best Answer Ever. Available Online: https://www.ecc.org.nz/Story?Action=View\&Story_id=837 Assessed Date 31/7/2015 
Fatoki, O. \& Garwe, D. (2010). Obstacles to the growth of new SMEs in South Africa: A principal Component analysis approach. African Journal of Business Management, 4(5):729-738.

Gangata. K., \& Matavire, E.H.M. (2013). Challenges facing SMEs in accessing finance from financial institutions: The case of Bulawayo, Zimbabwe. International Journal of Applied Research and Studies. 2(7) 1-10.

Gorora, G.P.K. \& Mago, S. (2013). Challenges of rural entrepreneurship in South Africa: insights from nkonkobe municipal area in the Eastern Cape Province. International Journal of Information Technology and Business Management. 16(1): 1-11.

Greve, B. (2009). The Labour Market Situation of Disabled People in European Countries and Implementation of Employment Policies: A Summary of Evidence from Country Reports and Research Studies, Report prepared for the Academic Network of European Disability experts (ANED). [Online] Available at: http://www.disabilityeurope.net. Accessed: 29 July 2015.

Heckman, J.J. (2000) Policies to foster human capital. Research in Economics, 54:3-56.

Herrington, M., \& Wood, E. (2003). Global entrepreneurship monitor, South African report.[Online]Available:http/www.gbs.nct.ac.za/gbswebb/userfiles/gemsouthafrica2000pdf. Accessed: 25 May 2015.

Horn, N., Huygen, P., Woodward, S. \& Smith, K. (2009). Human and Social Development National Qualification Framework Level 3: Student's Book. Northlands: Mcmillan.Iyiola O. \& Azuh, D. 2014. Women entrepreneurs as small-medium enterprise (sme) operators and their roles in socio-economic development in Ota, Nigeria. International Journal of Economics, Business and Finance. 2(1) 1-10.

Human Sciences Research Council. (2012). The low-achievement trap: Changing the culture of inefficiency in teaching. Review, 10(2), 16-18.

Idris, A.J \& Agbim (2015). Micro-Credit as a Strategy for Poverty Alleviation among Women Entrepreneurs in Nasarawa State, Nigeria. Journal of Business Studies Quarterly. 6(3) 122-143.

International Labour Organization (2015). Jobs, Gender and Small Enterprises in Bangladesh. Retrieved from http://www.cartierwomensinitiative.com/docs/ILO_Bangladesh.pdf

Iwu, C.G \& Nxopo, Z. (2015). Determining the specific support services required by female entrepreneurs in the South African tourism industry. African Journal of Hospitality, Tourism and Leisure. 4(2) 1-13.

Iyiola, O \& Azuh, D. (2014). Women entrepreneurs as small medium enterprise (SME) operators and their roles in socio-economic development in Ota, Nigeria. International Journal of Economics, Business and Finance, 2(1) $1-10$

Jalbert, S. E. (2000). Economic empowerment for women: An evaluation of the advocacy activities of the National Association of Business Women (NABW). Washington, D.C: Center for International Private Enterprise.

Jebadurai, D.J. (2007). An overview of problems of rural entrepreneurs in India. International Journal of Advanced Research in Management and Social Sciences, 2(7) 202-208.

Jogee, A. \& Callaghan, C.W. (2014). Segmentation of Mall Shopping Motivations in the South African Gauteng Provincial Context. Mediterranean Journal of Social Sciences, 5(9) 41-50

Jones, O., Macpherson, A \& Thorpe, R. (2010). Promoting learning in owner-managed small firms: Mediating artefacts and strategic space', Entrepreneurship \& Regional Development, 22(7) 649-73.

Kalombo, G. (2005). Understanding Political Corruption in Post-Apartheid South Africa: The Gauteng Experience (1994-2004). PhD thesis. University of the Witwatersrand.

Kayamba, M. (2007). Female entrepreneurs' cellular phone habits in Zambia and South Africa. Master of Arts in international communication thesis. Pretoria. University of South Africa.

Kgagara, M. R. (2011). An assessment of the attitude towards entrepreneurship among higher education students in Sedibeng district. Master in Business Administration. North-West University. Potchefstroom.

Knight, L.,Harland, C., Telgen, J., Thai, K.V., Callender, G \& McKen, K. (2012). Public Procurement: International Cases and Commentary. New York: Routledge.

Kuzilwa, J. (2005). The Role of Credit for Small Business Success: A Study of the National Entrepreneurship Development Fund In Tanzania. The Journal of Entrepreneurship, 14(2) 131-161.

Kyalo, T.N \& Kiganane, L.M. (2014). Challenges Facing Women Entrepreneurs in Africa -A Case of Kenyan Women Entrepreneurs. International Journal of Advances in Management, Economics and Entrepreneurship. 1(2) 1-8.

Luiz, J. \& Mariotti, M. (2011). Entrepreneurship in an emerging and culturally diverse economy: a South African survey of perceptions. South African Journal of Economic and Management Sciences. 14(1):47-65. 
Maas, G, \& Herrinton, M. (2006). Global Entrepreneurship Monitor (GEM). South African report. Cape Town: University of Cape Town.

Malebana, M.J. \& Swanepoel, E. (2015). Graduate entrepreneurial intentions in the rural provinces of South Africa. Southern African Business Review, 19 (1) 89-111.

Mandipaka F., (2014). Overview of Women Entrepreneurs in South Africa. Mediterranean Journal of Social Sciences. 5(9) 127-130.

Manerkar, G.A. (2015). Women Entrepreneurs in Goa: Issues and Challenges. Indian Streams Research Journal. $4(12)$ 1-8

Matiwane, M. (2005). South African Women entrepreneurship: A burgeoning force in our economy. A special report for SAWEN, an initiative of the DTI group.

Mbenzi, K.P. (2011). The role of government agencies in promoting SMMEs in Limpopo: A critical assessment. Unpublished Masters Dissertation. Stellenbosch, University of Stellenbosch.

Meyer, N. (2009). An investigation into the determinants of women entrepreneurship, Master in Business Administration. Mini-dissertation. North-West University, Potchefstroom.

Mitchell BC. (2004). Motives of African entrepreneurs: a case of South Africa. Journal of Entrepreneurship, 13(2) 167-183.

Mouton, N., Louw, G.P \& Strydom, G.L. (2013). Present-Day Dillemas and Challenges of the South African Tertiary System. International Business \& Economics Research Journal, 12(3) 285-300

Mwakikagile, G. (2008). South Africa and its people. Pretoria: New Africa Press.

Nani, G.V. (2011). Challenges faced by Zimbabwean urban women entrepreneurs. PhD Thesis. Bloemfontein: University of Free State.

Nieman, G \& Nieuwenhuizen, C. (2009). Entrepreneurship: A South African perspective. 2nd. Pretoria: Van Schaik.

Nkpoyen, F \& Bassey, G.E. (2012). Micro-lending as an empowerment strategy for poverty alleviation among women in Yala Local Government Area of Cross River State, Nigeria. International Journal of Business and Social Science, 32(18) 233-241.

Nxopo, Z. (2014). The Role of Government in Empowering Female Entrepreneurs in the Western Cape, South Africa. Master of Technology: Business Administration (Entrepreneurship). Cape Peninsula University of technology. Cape Town.

Nyamwanza, T., Mapetere, D. Mavhiki, S \& Dzingirai, C. (2012). Financial Management: Case Study of Gweru Women Entrepreneurs. International Journal of Business and Social Science, 3(18) 99-106.

Nyanga, T. (2013).Challenges Faced By Young Enterpreneurs at Mandava Market in Zvishavane, Zimbabwe. International Journal of Scientific \& Technology Research, 2(2) 113-117.

O’Neil, R.C. \& Viljoen, L. (2001). Support for Female Entrepreneurs in South Africa. Improvement or decline? Journal of Family Ecology and Consumer Sciences. (29) 37-44.

Ochieng, P.A \& Sije, A. (2013). Strategy adoption and women entrepreneurs in accessing credit facilities in Kenyan financial institutions a case of women entrepreneurs in Komala municipality, Kisumu Country. International Journal of Small Business and Entrepreneurship Research. 1(4) 1-10.

OED (Oxford English Dictionary). (2001). Solution. Oxford: Clarendon Press.

Olabisi, S.Y \& Olagbem, A.A. (2012). Human Capital and Women Entrepreneurs in Tye and Dye Micro-Business in Ogun State, Nigeria. Global Journal of Human Social Science, 12(5) 33-42.

Orford, J., Wood, E., Fischer, C., Herrington, M., \& Segal, N. (2003). Global Entrepreneurship Monitor: South African Executive Report, Cape Town: University of Cape Town, South Africa.

Pather, D. (2011). How to stop the rot in our school system. Performance in family and non-family firms: an analysis of SMEs. Journal of innovation and Entrepreneurship, 14(2) 1-20.

Phillips, M. Moos, M \& Nieman, G. (2014). The Impact of Government Support Initiatives on the Growth of Female Businesses in Tshwane South Africa. Mediterranean Journal of Social Sciences. 5(15) 85-92.

Pooe, D.R.I., Mafini, C \& Makhubele, D.T (2015). Investigating Municipal Procurement Challenges in South Africa: A Qualitative Study. International Business \& Economics Research Journal, 14(1) 67-78.

Pretorius, R., \& Shaw, G. (2004). Business plan in bank-decision making when financing new businesses. South Africa Journal of Economic and Management Sciences, 7(2) 221-241.

PRICE, D.P., STOICA, M. \& BONCELLA, R.J. (2013). The relationship between innovation, knowledge, and performance in family and non-family firms: an analysis of SMEs. Journal of innovation and Entrepreneurship, 14(2) 1-20.

Sarri, K. \& Trihopoulou, A. (2005). Female entrepreneur's personal characteristics and motivation: a review of the 
Greek Situation. Women in Management Review, 20(1) 24-36.

Senatla, M. (2011). Energy demand projections and relevance of income dynamics in Gauteng's residential sector. Journal of Energy in Southern Africa, 22(4) 31-47

Sibanda, K., Mishi, S \& Tsegaye (2015). The Impact of Oil Prices on Sectorial Employment in South Africa. International Business \& Economics Research Journal. 14(2) 287-296,

Singh, R. (2012). Women entrepreneurship issues, challenges and empowerment through self help groups: an overview of Himachal Pradesh. International Journal of Democratic and Development Studies, 1(1) 45-58.

Sinha, S. (2005). Developing women entrepreneurs in South Asia: Issues, Initiatives and Experiences UN ESCAP: Economic and Social Commission for Asia and the Pacific. Women entrepreneurs in developing countries. [Online] Available: pdf file [Accessed: 3 April 2015].

Stevenson, A. (2010). Oxford Dictionary of English. $3^{\text {rd }}$ ed. Oxford University Press. New York

Stevenson, L. \& Onge, A. (2005). Support for growth-oriented women entrepreneurs in Ethiopia. International Labour Office: Geneva.

Strauss, A. L., \& Corbin, J. (1990). Basics of Qualitative Research: Grounded Theory Procedures and Techniques. Newbury Park, CA: Sage.

The U.S. Small Business Administration. (2009). Toward Effective Education of Innovative Entrepreneurs in Small Business: Initial Results from a Survey of College Students and Graduates. Available Online: https://www.sba.gov/sites/default/files/rs353tot.pdf Assessed Date 31/7/2015.

Thuaibah, A.B., Azlah, M.A., Rozeyta, O., Hishamuddin, M.S \& Noorizwan, S. (2007). Women's involvement in entrepreneurship in Johor: a study about critical success factors in achievement and failure in handling business, Project report. Universiti Teknologi Malaysia

Timmons, J., \& Spinelli, S. (2009). New Venture Creation, Entrepreneurship for the 21 st Century. McGraw-Hill Higher Education, 8th ed/2009.

Uchenna, O.I \& Kurub N.P. (2014). Women Entrepreneurship in Malaysia: An Empirical Assessment of the Challenges Faced by Micro and Small Business Owners in Kuching-Sarawak. International Journal of Humanities Social Sciences and Education. 1(4) 48-58.

Valla, S. (2001). Barriers facing female entrepreneurs: A study in the Gauteng Province, South Africa. MBA thesis. University of Wales.

Van der Merwe, L.H. (2008). Socio Economic implications: KKNK in Oudtshoorn. Unpublished M.Com dissertation. Potchefstroom: North Western University, Faculty of Economic and Management Sciences.

Van Der Merwe, M. (2008). A study of discrimination against women entrepreneurs when applying for financial assistance. Phil thesis, University of Pretoria: Pretoria.

Véras, E.Z. (2015). Female Entrepreneurship: from Women's Empowerment to Shared Value Creation. International Journal of Management Science and Business Administration, 1(3) 50-63.

Verheul, I., Van Stel, A., \& Thurik, R. (2004). Explaining female and male entrepreneurship across 29 countries. Scientific Analysis of Entrepreneurship and SMEs, Working Paper, May.

Vinesh, L. (2014). Role of women entrepreneurs in India. Global Journal of Finance and Management. 6(5) 473480.

Visser, D. (2002), Constraints facing tourism entrepreneurs in South Africa: A study in the Gauteng and Mpumalanga Provinces, South Africa, DCom thesis, University of Pretoria, Pretoria.

Wasilczlik, J. \& Zieba, K. (2008). Female entrepreneurship in transitional economies: the case of Poland. Journal of Small Business and Entrepreneurship, 21(2) 153-170.

Wilson, J. (2010). Essentials of business research. A guide to doing your research project. Great Britain: Sage Publications.

Yogendrarajah, R. (2011). Empowering rural women through microcredit on poverty alleviation, self-employment and health nutrition under post war development. Gumbard Business Review, 6(2), 1-17.

Zikmund, W.G., Babin, B.J., Carr, J.C., \& Griffin, M. (2010). Business research methods. $8^{\text {th }}$ ed. Canada: South Western Cengage Learning.

Zindiye, S., Chiliya, N. \& Masocha, R. (2012). The impact of Government and other Institutions' support on the Performance of Small and Medium Enterprises in the Manufacturing Sector in Harare, Zimbabwe. International J journal of Business Management Economics Research 3(6) 655-667. 


\section{NOTES}

